\title{
TERRESTRIAL MOLLUSKS (GASTROPODA) OF THE SLOVECHANSKO-OVRUTSKY RIDGE (ZHYTOMYR REGION, NORTHERN UKRAINE)
}

\author{
I. Balashov \\ Schmalhausen Institute of Zoology, of the NAS of Ukraine, \\ B. Chmielnicky str., 15, Kyiv, 01601 Ukraine \\ E-mail: igor_balashov@ukr.net
}

Received 8 December 2011

Accepted 5 March 2012

\begin{abstract}
Terrestrial Mollusks (Gastropoda) of the Slovechansko-Ovrutsky Ridge (Zhytomyr Region, Northern Ukraine). Balashov I. - Thirty-five species of terrestrial mollusks were found in the Slovechansko-Ovrutsky ridge. Findings of Clausilia cruciata, Ruthenica filograna and Monachoides vicinus are especially interesting. Reproductive system of Morlina glabra is described. Problems of the conservation of terrestrial mollusks in the region are discussed.
\end{abstract}

Key words: terrestrial mollusks, Gastropoda, conservation, Slovechansko-Ovrutsky ridge, Ukraine.

\begin{abstract}
Наземные моллюски (Gastropoda) Словечанско-Овручского кряжа (Житомирская область, северная Украина). Балашёв И. - На территории Словечанско-Овручского кряжа зарегистрированы 35 видов наземных моллюсков. Особо интересны находки таких видов как Clausilia cruciata, Ruthenica filograna и Monachoides vicinus. Приведено описание половой системы Morlina glabra. Обсуждаются проблемы охраны наземных моллюсков в регионе.
\end{abstract}

Ключевые слова: наземные моллюски, Gastropoda, охрана, Словечанско-Овручский кряж, Украина.

Slovechansko-Ovrutsky ridge (further in text SOR) is a small upland on the Polesian Lowland in Ovruch district of Zhytomyr region (Northern Ukraine) at $20 \mathrm{~km}$ from the border between Ukraine and Belarus. Its area is about $490 \mathrm{~km}^{2}$ and extension is about $50 \mathrm{~km}$. SOR is raised above surrounding lowland on more than $100 \mathrm{~m}$, with minimum high about $200 \mathrm{~m}$ and maximum high $321 \mathrm{~m}$ (Smyk, 1964; Shelyag-Sosonko et al., 1987; Khomyak, Didukh, 2005 et al.). It is the highest point in radius more than $150 \mathrm{~km}$ and highest point of the Polesie. The surface of SOR is indented by the valleys and ravines, which provide diversity of the habitation conditions. On the territory of SOR many interesting locations of non-typical for Polesie plants were found. Particularly significant are the most north-eastern location of durmast (Quercus petraea) and especially the most northern location of yellow azalea (Rhododendron luteum), which main range is located in Caucasus and Asia Minor, more than $1000 \mathrm{~km}$ far from the SOR. Among the plants of SOR, both the most south locations of some northern species ( Carex pauciflora, Listera cordata et al.), and the most north-eastern locations of some southern and western European species (durmast, yellow azalea, English ivy et al.) are known (Smyk, 1964; Shelyag-Sosonko et al., 1987; Khomyak, Didukh, 2005) were mentioned.

The terrestrial mollusks on the SOR are poorly studied. In 1988 mollusks were collected on two nearby plots in the basin of the Chervonka River by Dr. A. A. Baidashnikov. This material is partly described in two articles dealing with the terrestrial mollusks of Ukrainian Polesie (Baidashnikov, 1992, 1996). New material was collected on the SOR in 2011 by the author of this article. Any other collections of terrestrial mollusks from the SOR are unknown.

\section{Material and methods}

During 10-12 October, 2011 about 800 specimens of 34 terrestrial mollusks' species were collected on the western part of SOR. Material collected by Dr. Baidashnikov on August 25, 1988 in the basin of the Chervonka River, which includes about 200 specimens of 18 species, was also studied. All this material is kept in the Collection of terrestrial mollusks of Schmalhausen Institute of Zoology (Kyiv). Main collection locations (fig. 1): 1 vicinities of Gorodec village, 23 and 24 squares of Gorodec forestry, Korobanica tract, hornbeam-durmast for- 


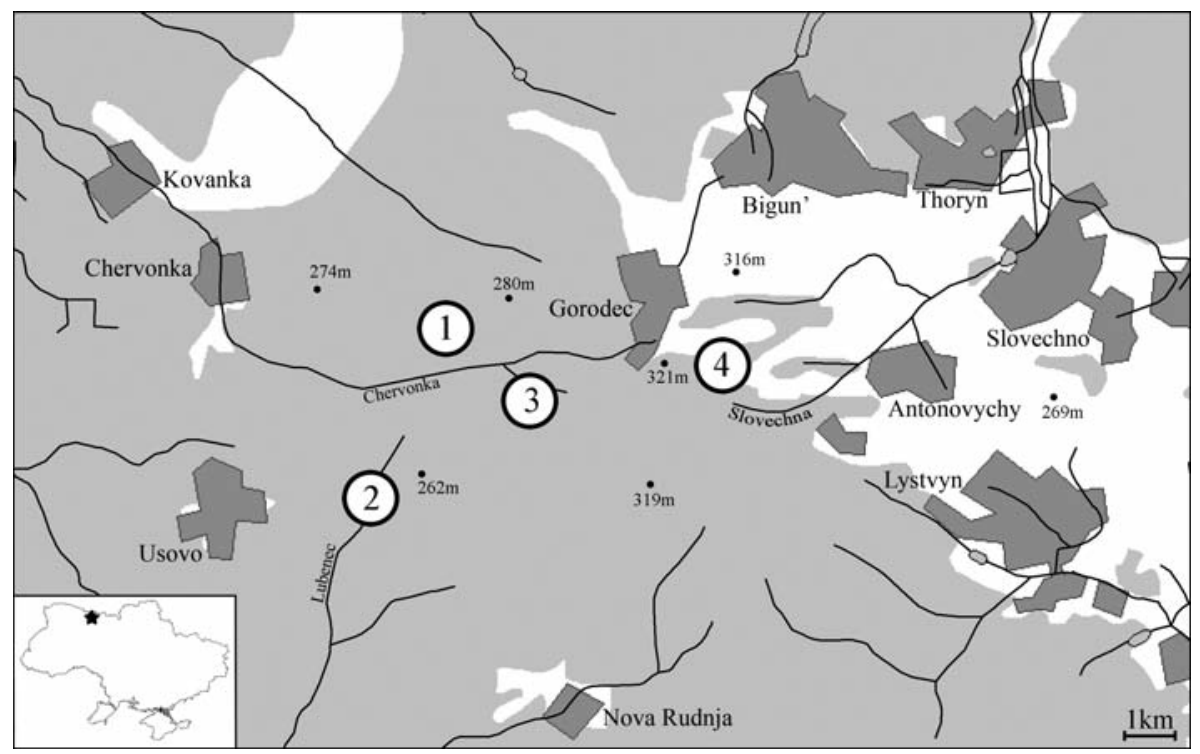

Fig. 1. Main collection locations: 1-4 - see "Material and methods"; dark-grey — settlements; light-grey forests; white - open plots; black lines - rivers.

Рис. 1. Основные пункты сбора материала. Условные обозначения: 1-4 - см. "Material and methods"; темно-серый - населённые пункты; светло-серый - леса; белый - открытые участки; чёрные линии - реки.

est, accumulations of dead wood, collected only from the dead wood and alive trees (litter was not studied), 25.08.1988; 2 - vicinities of Usovo village, along the Lubenec River, birch-oak-pine forest, about $230 \mathrm{~m}$, $51^{\circ} 20^{\prime} 20^{\prime}$ 'N 28 $10^{\prime} 15^{\prime \prime}$ E, 10.10.2011; 3 - vicinities of Gorodec village, along the stream in the basin of the Chervonka River, southward to Usovo-Gorodec road, hornbeam-alder-oak forest, about $270 \mathrm{~m}, 51^{\circ} 21^{\prime} 10^{\prime \prime} \mathrm{N}$ $28^{\circ} 12^{\prime} 45^{\prime}$ 'E, 11.10.2011; 4 - vicinities of Gorodec village, large deep ravine with stream (basin of the

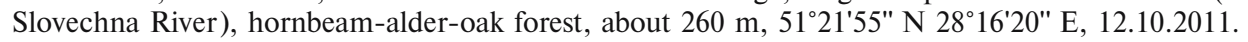

\section{Results and discussion}

In total, 35 species of terrestrial mollusks are represented in the studied material (table 1). Findings of such species as Clausilia cruciata (Studer, 1820), Ruthenica filograna (Rossmässler, 1836) and Monachoides vicinus (Rossmässler, 1842) are especially interesting. These species have not been previously reported in Zhytomyr region (Baidashnikov, 1992, 1996; Balashov et al., 2007). In the case of C. cruciata, it is the second record of this species in Ukraine outside Carpathians. The range of this species is parted in two main pieces - Alpine-Carpathian and northern-central-European (Scandinavia, Baltic countries, sporadic in Belarus and in north-western part of European Russia) (Kerney et al., 1983; Sysoev, Schileyko, 2009). For Ukraine outside Carpathians this species was mentioned by Adamovich (Adamowicz, 1939; Baidashnikov, 1992, 1996) from Rivne region (Volyn, north-western Ukraine). However accuracy of the determination in this case is doubtful for some authors (Sverlova, Gural, 2005), and in Ukraine this species is usually mentioned only from the Carpathians (Sysoev, Schileyko, 2009 et al.). Consequently, this record could be considered as the first reliable record of this species in Ukraine outside Carpathians. Besides, the nearest known population of C. cruciata in Carpathians is at the distance of more than $400 \mathrm{~km}$ from the SOR. This record of this species is also the most southern one on the East European Plain. I collected 14 specimens of $C$. cruciata under bark of the old fallen alder trunks on the banks of two streams. Most specimens were collected on the location N 3 and one empty shell was collected on the location $\mathrm{N} 4$ (fig. 1). The height of collected shells is $8.6-10.3 \mathrm{~mm}$, diameter 2.2-2.5 $\mathrm{mm}$, the shells are clearly and rarely ribbed (fig. 2). 
Table 1. Terrestrial mollusks of the studied locations on the Slovechansko-Ovrutsky ridge Таблица 1. Наземные моллюски изученных участков Словечанско-Овручского кряжа

\begin{tabular}{|c|c|c|c|c|}
\hline Species & Location $\mathrm{N} 1^{*}$ & Location N 2 & Location N 3 & Location $\mathrm{N} 4$ \\
\hline Platyla polita (Hartmann, 1840) & - & - & + & + \\
\hline Carychium minimum Müller, 1774 & - & - & + & + \\
\hline Carychium tridentatum (Risso, 1826) & - & - & + & ++ \\
\hline Cochlicopa lubricella (Porro, 1838) & - & + & + & + \\
\hline Cochlicopa lubrica (Müller, 1774) & - & - & + & + \\
\hline Cochlicopa nitens (Gallenstein, 1848) & - & - & + & - \\
\hline Vertigo pusilla Müller, 1774 & - & + & + & + \\
\hline Vertigo substriata (Jeffreys, 1833) & - & + & + & + \\
\hline Columella edentula (Draparnaud, 1805) & - & - & + & + \\
\hline Acanthinula aculeata (Müller, 1774) & + & + & ++ & ++ \\
\hline Ruthenica filograna (Rossmässler, 1836) & - & - & - & + \\
\hline Cochlodina laminata (Montagu, 1803) & ++ & + & ++ & ++ \\
\hline Cochlodina orthostoma (Menke, 1830) & ++ & - & + & + \\
\hline Laciniaria plicata (Draparnaud, 1801) & ++ & + & ++ & ++ \\
\hline Bulgarica cana (Held, 1836) & + & - & - & - \\
\hline Clausilia cruciata (Studer, 1820) & - & - & + & + \\
\hline Punctum pygmaeum (Draparnaud, 1801) & - & + & + & ++ \\
\hline Discus ruderatus (Hartmann, 1821) & ++ & ++ & ++ & ++ \\
\hline Vitrea contracta (Westerlund, 1871) & + & - & - & + \\
\hline Aegopinella pura (Alder, 1830) & + & + & + & ++ \\
\hline Aegopinella minor (Stabile, 1864) & + & - & + & + \\
\hline Perpolita hammonis (Strøm, 1765) & + & ++ & ++ & + \\
\hline Perpolita petronella (Pfeiffer, 1853) & + & - & + & + \\
\hline Morlina glabra (Rossmässler, 1836) & + & - & - & + \\
\hline Zonitoides nitidus (Müller, 1774) & ++ & - & + & ++ \\
\hline Euconulus fulvus (Müller, 1774) & ++ & ++ & ++ & ++ \\
\hline Limax cinereoniger Wolf, 1803 & + & + & + & + \\
\hline Lehmannia marginata (Müller, 1774) & + & - & + & - \\
\hline Malacolimax tenellus (Müller, 1774) & + & + & + & + \\
\hline Deroceras laeve (Müller, 1774) & - & + & - & + \\
\hline Perforatella bidentata (Gmelin, 1791) & - & - & - & + \\
\hline Monachoides vicinus (Rossmässler, 1842) & - & + & - & + \\
\hline Arion subfuscus (Draparnaud, 1805) & + & + & + & + \\
\hline Succinella oblonga (Draparnaud, 1801) & - & + & - & + \\
\hline Succinea putris (Linnaeus, 1758) & - & + & - & + \\
\hline Number of species (35 in total) & 18 & 18 & 26 & 32 \\
\hline
\end{tabular}

Note: "Location N 1-4" - see "Material and methods" and fig. 1; "+" - species is present in this location; "++" - species is numerous in this location; * - on the location N 1 mollusks were collected only from the dead wood and alive trees, litter was not studied.

Snail $R$. filograna is a species rare in Ukraine; it was not previously reported from the central Polesie (Baidashnikov, 1992, 1996; Balashov et al., 2007). However, finding of this species on the SOR does not expand known range borders of this species. Single records of $R$. filograna took place on the surrounding territories: in the western Polesie (Baidashnikov, 1992, 1996), in the eastern part of Podolian Upland (Balashov, Baidashnikov, 2012), in the forest-steppe zone in Middle Dnieper Area (Balashov, Baidashnikov, 2010), in the south-western part of Middle Russian Upland (Balashov et al., 2009) and in Belarus (Sysoev, Schileyko, 2009).

M. vicinus is a Carpathian subendemic, or, as it was characterized by Baidashnikov (1996), a Carpatho-Podolian species. Most of its findings took place in the Carpathians and in Podolian Upland (Kerney et al., 1983; Sysoev, Schileyko, 2009). On the Podolian Upland this species is common up to its eastern extremity (Balashov, Baidashnikov, 2012), however in the more eastern regions M. vicinus was not found (Balashov, Baidashnikov, 

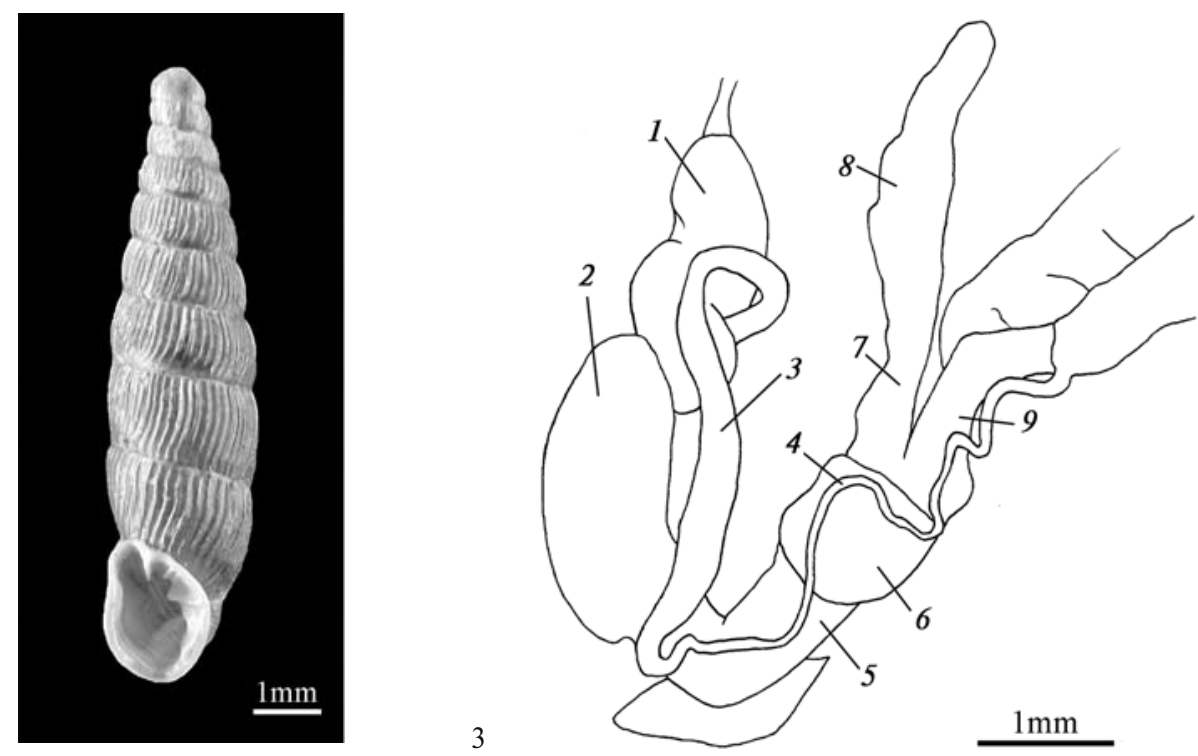

Fig. 2. Shell of Clausilia cruciata from the location N 3.

Рис. 2. Раковина Clausilia cruciata из местонахождения № 3.

Fig. 3. Reproductive system of Morlina glabra from the location N 4: 1 - flagellum; 2 - penis; 3 - epiphallus; 4 - spermoviduct; 5 - vagina; 6 - perivaginal gland; 7 - spermathecal shaft; 8 - reservoir of spermatheca; 9 - free oviduct.

Рис. 3. Половая система Morlina glabra из местонахождения № 4: 1 - флагеллум; 2- пенис; 3 - эпифаллус; 4 - семяпровод; 5 - вагина; 6 - околовагинальная железа; 7 - семяприемник; 8 - резервуар семяприемника; $9-$ яйцевод.

2010; Balashov, Gural-Sverlova, 2012). In Polesie this species was found only in the Volyn (Baidashnikov, 1992, 1996; Balashov, Gural-Sverlova, 2012) and was not found in Belarus (Sysoev, Schileyko, 2009). Consequently, record of this species on the SOR essentially extends the known range of this species to the north-east.

Presence of the Morlina glabra (Rossmässler, 1836) on the SOR is also interesting. This species was mentioned for this territory by Baidashnikov (1992, 1996). Similarly to M. vicinus, this species in Ukraine is known from Carpathians (Sysoev, Schileyko, 2009; Balashov, Gural-Sverlova, 2012), Podolian Upland (Balashov, Baidashnikov, 2012; Balashov, Gural-Sverlova, 2012), Volyn (Baidashnikov, 1992, 1996; Balashov, GuralSverlova, 2012) and, moreover, from one location in the forest-steppe zone in Middle Dnieper Area (Balashov, Baidashnikov, 2010). In Belarus, this species is also absent (Sysoev, Schileyko, 2009). Consequently, as well as M. vicinus, M. glabra on the SOR lives on the north-eastern border of its range. It is notable that the structure of the reproductive system of M. glabra from the eastern plain part of its range is not described in literature. At the same time this species belongs to the group, which taxonomy is based mainly on the structure of the reproductive system. It seems interesting, therefore, to adduce illustration of this species reproductive system (fig. 3). Generally reproductive system is found to be similar to that of the specimens from Poland (Riedel, 1957) and IvanoFrankivsk region of Ukraine (Schileyko, 2003): proper penis is moderately long, extended in the middle, not curved; flagellum is little shorter than penis, strongly curved; epiphallus is long, extended in the middle, curved; vagina shorter and little more narrowed than penis; perivaginal gland is little wider than vagina; spermatheca is moderately long, its reservoir is poorly demarcated. However, specimen from Ivano-Frankivsk region has much longer vagina (Schileyko, 2003). The largest shell of M. glabra collected on the SOR has diameter $12.5 \mathrm{~mm}$. 
The richest species composition of terrestrial mollusks is registered along the stream in deep ravine, location $\mathrm{N} 4$ (table 1). It is notable that quite similar species composition was registered in the comparable ravines of Kaniv Upland in the Middle Dnieper Area (Balashov, 2006; Balashov, Lukashov, 2007; Balashov, Baidashnikov, 2010), on the distance of more than $300 \mathrm{~km}$ from the SOR. Species composition of terrestrial mollusks in these regions as a whole is essentially different (Balashov et al., 2007). It is particularly significant that both in ravines of Kaniv Upland and in ravines of SOR such rare species as Platyla polita (Hartmann, 1840), R. filograna, Bulgarica cana (Held, 1836), Vitrea contracta (Westerlund, 1871) and M. glabra are present. Furthermore, Aegopinella pura (Alder, 1830) and Malacolimax tenellus (Müller, 1774), quite common in Polesie, are known in the forest-steppe Dnieper Area only from few records including ravines of Kaniv Upland. However, in Kaniv ravines such species as C. cruciata, M. vicinus and Vertigo substriata (Jeffreys, 1833) are absent. Species Cochlodina orthostoma (Menke, 1830) and Perpolita petronella (Pfeiffer, 1853), which are very rare in the Dnieper forest-steppe (Balashov, 2006; Balashov, Lukashov, 2007; Balashov, Baidashnikov, 2010) are not found in the Kaniv ravines too. At the same time, on the territory of SOR (and Polesie in whole ) Sphyradium doliolum (Bruguiere, 1792) is not registered, but it inhabits Kaniv ravines on the north-eastern border of its range (Balashov, Baidashnikov, 2010). Moreover, from species registered in Kaniv ravines, several widespread species are also absent in SOR. There is no doubt that such peculiarity of species compositions in ravines is not a coincidence. The specific richness of terrestrial mollusks in the ravines was mentioned in many territories. It is specified mainly by the specific microclimate with increased humidity and smooth temperature drop, and moreover by the difficulty of human access (Balashov, 2006; Balashov, Lukashov, 2007; Balashov et al., 2007; Balashov, Baidashnikov, 2010, 2012 et al.).

It should be taken into consideration that species composition of terrestrial mollusks in 4 described locations (table 1) cannot be characterized as a typical for most part of SOR. The most part of analyzed area is covered by the secondary anthropogenic pine and birch forests composing $87 \%$ of the SOR forests (Khomyak, Didukh, 2005). Species composition of terrestrial mollusks in such forests is poor and represented mostly by the Euconulus fulvus (Müller, 1774), Perpolita hammonis (Strøm, 1765), M. tenellus and Arion subfuscus (Draparnaud, 1805) only. Studied plots of forest with predominance of oak, durmast, hornbeam and alder, are remains of natural forests, which survive mostly on the banks of streams and rivers. Species composition registered in these forests (table 1) probably was typical for the most part of SOR, or, at least, its western part. But reduction of the oak, durmast, hornbeam and alder, and also realization of forestry activity in remained forests, entails extinction of these mollusk species on the most part of SOR. Primarily in the western part of the SOR share of the oak forests was at least $30 \%$, but now it is $2.5 \%$ (Khomyak, Didukh, 2005). Even if forests are not destroyed totally, sanitary felling may have extremely destructive influence on mollusks, especially such rare species as C. cruciata, C. orthostoma, B. cana and M. glabra. Such forestry actions involve in forests minimization of dead wood capacity, which is main environment for these species of mollusks. On the plots where sanitary felling is taking place, above mentioned species do not inhabit. Locations N 3 and partly N 1 are positioned on the territory of the small forest reserve (Rus. «заказник») of local importance "Slovechanskij Krjazh" ("Slovechanskij Ridge"), however sanitary felling is probably not forbidden there. It is very concerned that in the many of Ukrainian reserves, national nature parks and other protected areas, the sanitary felling officially and legally takes place. According to the legislation of Ukraine, on the protected territories the sanitary felling is regulated by the same standard acts as on the territories not protected. At that in the period of 2003-2009 share of the sanitary felling in all procured wood in Ukraine amounts $56 \%$ (60.5 millions $\left.\mathrm{m}^{3}\right)($ State committee..., 2010). On the protected territories sanitary felling is for- 
bidden only in the case if it is clearly stipulated in the policy of particular protected area. However in the overwhelming majority of cases it is not stipulated. As a result protected forests in Ukraine have no sufficient significance in the conservation of forest biodiversity in Ukraine at whole, and first of all of organisms inhabiting dead wood, including mollusks.

It was proposed to create a branch of the Polisskiy Nature Reserve between the Kovanka, Usovo and Gorodec villages on the area of $120 \mathrm{~km}^{2}$ (Shelyag-Sosonko et al., 1987). In my opinion, joining these territories to the Polisskiy Reserve is very expedient. Moreover, the upper basin of the Slovechna River and of some its confluents (between Gorodec and Antonovychy villages) should also be joined to the Polisskiy Reserve. In the locations N 1, 3 and 4 (fig. 1) and in other locations of durmast, oak, hornbeam and alder forest, it is necessary to create protected cores, where all forestry activity should be forbidden. It is especially necessary for the conservation of relict populations of $\mathrm{C}$. cruciata, whose condition in the plain part of Ukraine is corresponded to the IUCN category Critically Endangered by the criterions B 1 a, b and B 2 a, b (IUCN..., 2001; Guidelines..., 2003). It is necessary to include this species in the red lists of Zhytomyr and Rivne regions. Furthermore, among the species of the SOR, such snails as $P$. polita, R. filograna, C. orthostoma, B. cana, V. contracta, M. glabra and M. vicinus are also recommended to be included in the Red List of Zhytomyr region.

It should be taken into consideration that terrestrial mollusk species composition of SOR is still studied not well enough. It is very possible that other rare species of terrestrial mollusks will be found there, including those not typical for the Polesie.

Adamowicz J. Materialy do fauny mieczakow (Mollusca) Polesia // Fragmenta Faunistica Musei Zoologici Polonici. - 1939. - 4, 3. - P. 13-89.

Baidashnikov A. A. Terrestrial mollusk fauna of the Ukrainian Polesie area. Communication 1. Species composition and connection with vegetative cover // Vestnik zoologii. - 1992. - N 4. - P. 13-19. - Russian : Байдашников А. А. Наземная малакофауна Украинского Полесья. Сообщение 1. Видовой состав и связь моллюсков с растительным покровом.

Baidashnikov A. A. Terrestrial mollusk fauna of the Ukrainian Polesie area. Communication 2. Origins of the recent molluskan assemblages // Vestnik zoologii. - 1996. - N 3. - P. 3-12. Russian : Байдашников А. A. Наземная малакофауна Украинского Полесья. Сообщение 2. Формирование современных малакокомплексов.

Balashov I. A. The role of the forest ravines in the distribution of terrestrial molluscs on the Kaniv Upland // Ecologo-funkcionalni ta faunistychni aspekty doslidjennya moluskiv, yih rol u bioindykazii stanu navkolishnogo seredovysha. - Zhytomyr : Vyd. Zhyt. Univer., 2006. - 2. - P. 19-22. - Russian : Балашёв И. А. Значение лесных оврагов в распространении наземных моллюсков (Mollusca: Gastropoda) Каневской возвышенности.

Balashov I. A., Baidashnikov A. A. Terrestrial molluscs (Gastropoda) of the forest-steppe in the Dnieper Area and their confinement to different phytocenoses // Vestnik zoologii - 2010. - 44, N 4. - P. 309-316. Russian : Балашёв И. А., Байдашников А. А. Наземные моллюски (Gastropoda) лесостепного Приднепровья и их фитоценотическая приуроченность.

Balashov I. A., Baidashnikov A. A. Terrestrial mollusks (Gastropoda) of the Vinnytsia oblast and their biotopical preferences // Vestnik zoologii - 2012. - 46, N 1. - P. 19-28. - Russian : Балашёв И. А., Байдашников А. А. Наземные моллюски (Gastropoda) Винницкой области и их биотопическая приуроченность.

Balashov I. A., Biatov A. P., Vasyliuk A. V. Species composition and confinement to different phytocenoses of terrestrial mollusks (Gastropoda, Pulmonata) in the "Homilshanski Lisy" National Nature Park (Ukraine, Kharkiv region) // Vestnik zoologii - 2009. - 43, N 4. - P. 355-360. - Russian : Балашёв И. А., Биатов А. П., Василюк А. В. Видовой состав и фитоценотическая приуроченность наземных моллюсков (Gastropoda, Pulmonata) Национального природного парка «Гомольшанские леса» (Украина, Харьковская обл.).

Balashov I., Gural-Sverlova N. An annotated checklist of the terrestrial molluscs of Ukraine // Journal of Conchology. - 2012. - 41, N 1. - P. 91-109.

Balashov I. A., Lukashov D. V. Terrestrial molluscs of the Kaniv nature reserve // Zapovidna sprava v Ukraini. 2007. - 13 (1-2). - Р. 75-79. - Ukrainian : Балашов I. О. , Лукашов Д. В. Наземні молюски Канівського природного заповідника // Заповідна справа в Україні.

Balashov I. A., Lukashov D. V., Sverlova N. V. Terrestrial molluscs of the Middle Dnieper Area. Guide. - Kyiv : Phytosociocentre, 2007. - 132 p. - Ukrainian : Балашов I. О., Лукашов Д. В., Сверлова Н. В. Наземні молюски Середнього Придніпров’я. 
Khomyak I. V. , Didukh Ya. P. The particularities of the accommodation woodland structure of the SlovechanskoOvruchsky ridge // Ukrainian Phytosociological Collection. - Kyiv, 2005. - Is. C, vol. 23. P. 91-106. - Ukrainian : Хом'як I. В., Дідух Я. П. Територіальний розподіл лісових екосистем Словечансько-Овруцького кряжу // Український фітоценологічний збірник.

IUCN Red List Categories and Criteria: Version 3. 1. - IUCN, 2001. - 30 p.

Guidelines for Application of IUCN Red List Criteria at Regional Levels. - IUCN, 2003. - 26 p.

Kerney M. P., Cameron R. A. D., Jungbluth J. H. Die Landschnecken Nord- und Mitteleuropas. - Hamburg ; Berlin : Parey, 1983. - 384 S.

Riedel A. Revision der Zonitiden Polens (Gastropoda) // Annales Zoologici. - 1957. - 16, N 23. - S. 361-465.

Schileyko A. A. Treatise on Recent Terrestrial Pulmonate molluscs // Ruthenica.- 2003. - Suppl. 2, p. 10. P. 1309-1465.

Shelyag-Sosonko Yu. R., Stoyko S. M., Didukh Ya. P. et al. Perspective system of the reserved objects of Ukraine. Kyiv : Naukova dumka, 1987. - 292 p. - Russian : Шеляг-Сосонко Ю. Р., Стойко С. М., Дидух Я. П. и др. Перспективная сеть заповедных объектов Украины.

Smyk G. K. Slovechansko-Ovruchskij ridge // Pryroda. - 1964. - N 12. - P. 63-64. - Russian : Смык Г. К. Словечанско-Овручский кряж.

State committee of the forestry of Ukraine. Forestry of Ukraine. - Kyiv : Vydavnychiy dim "ECO-inform", 2010. - 64 p. - Ukrainian : Державний комітет лісового господарства України. Лісове господарство України.

Sysoev A., Schileyko A. Land snails and slugs of Russia and adjacent countries. Pensoft Series Faunistica 87 Sofia ; Moscow : Pensoft Publishers, 2009. - 455 p.

Sverlova N. V., Gural R. I. Guide to terrestrial molluscs of the western Ukraine. - Lviv, 2005. - 218 p. Ukrainian : Сверлова Н. В., Гураль Р. I. Визначник наземних молюсків заходу України. 